Chirurgia (2020) 115: 715-725

No. 6, November - December

Copyright@ Celsius

http://dx.doi.org/10.21614/chirurgia.115.6.715

\title{
Experience of the Colentina Clinical Hospital Surgery Clinic in the Treatment of COVID-19 Patients Hospitalised in the Period March - August 2020
}

\author{
Cristian Botezatu', , Dan Andraș ${ }^{1,2}$, Cosmin Popa ${ }^{1,2}$, Marius Petruțescu', Delia Boța' ${ }^{1}$, Constantin Tihon', Bogdan Ghiță' \\ Adrian Zarafin', Gabriel Vlăsceanu', Mircea Radu', Valentin Popescu' ${ }^{1,2}$, Bogdan Stelian Mastalier Manolescu', ${ }^{1,2}$ \\ ${ }^{1}$ Colentina Clinical Hospital, General Surgery Clinic, Bucharest, Romania \\ 2"Carol Davila" University of Medicine and Pharmacy, Bucharest, Romania
}

${ }^{*}$ Corresponding author:

Dan Andras, MD

"Carol Davila" University of Medicine and Pharmacy

Colentina Clinical Hospital

General Surgery Clinic

Bucharest, Romania

E-mail: dr.danandras@gmail.com

\section{Rezumat}

Experienta Clinicii de Chirurgie a Spitalului Clinic Colentina în tratamentul pacientilor COVID-19 internati în perioada martie - august 2020

Introducere: SARS-CoV-2 este un Betacoronavirus, încadrat în subgenul Sarbecovirus al familiei Coronaviridae, distinct antigenic față de SARS CoV, cu care are similitudine genetică în proporție de cca $76 \%$ din nucleotide (1). El produce la om o afecțiune, Covid-19, care interesează în principal aparatul respirator, prin mecanisme de tip inflamator şi procoagulant la nivel de microcirculație alveolară.

Material şi Metodă:Au fost analizate 145 cazuri, pacienți infectați cu SARS-CoV-2, tratați în Clinica Chirurgie Colentina în perioada martie-august 2020, în vederea identificării unor elemente care să ajute la îmbunătățirea managementului medical al acestor pacienți din perspective multiple.

Discuții:A existat o predominanță uşoară a afectărilor masculine, iar vârstele interesate au fost majoritar de peste 60 ani. Cazurile care au necesitat operație au fost într-o minoritate absolută (14 cazuri). Operațiile s-au efectuat doar în condiții de urgență chirurgicală. Mortalitatea a fost mare (24,13\%).

Cuvinte cheie: Sars-cov-2, Covid-19, tratament chirurgical
Received: 28.09 .2020

Accepted: 24.11 .2020

\section{Abstract}

Introduction: SARS-CoV-2 is a Betacoronavirus belonging to the 
Sarbecovirus subgenus of the Coronaviridae family, antigenically distinct from SARS CoV, with which it has a genetic similarity of about $76 \%$ of nucleotides (1). It causes the Covid-19 disease in humans, which mainly affects the respiratory system, through inflammatory and procoagulant mechanisms at the level of alveolar microcirculation.

Material and Method: There are 145 patients infected with SARS-CoV-2, treated in the Colentina Surgery Clinic during March-August 2020, whose cases were analysed to identify some elements that would help to improve the medical management of these patients from multiple perspectives. Discussion: There was a slight predominance of male impairments, and the ages of interest were mostly over 60 years. The cases that required surgery were in an absolute minority (14 cases). The operations were performed only in conditions of a surgical emergency. Mortality was high $(24,13 \%)$.

Key words: Sars-cov-2, Covid-19, surgical treatment

\section{Introduction}

Colentina Surgery Clinic was the first medical facility in Romania to perform surgical activities exclusively on Covid patients. Following the decision of 16 March 2020, Colentina Clinical Hospital was designated the only Covid Support Hospital in Bucharest. Thus, it was the only institution in Romania to have this kind of experience. This decision was initially based on the proximity to the National Institute of Infectious Diseases "Prof. Dr. Matei Bals", a criterion that soon became utterly irrelevant.

Due to this context, we had the opportunity to analyse all hospitalised cases during March-August 2020 to identify elements that would improve the medical management of these patients.

Following the declaration of the state of emergency in Romania due to the new Coronavirus, the Romanian TechnicalScientific Support Group had a meeting on the management of highly contagious diseases in Romania on 29 January 2020.

During the meeting, an analysis was made by the representatives of the Romanian Ministry of Internal Affairs, the Ministry of Health and the Ministry of National Defense, which revealed insufficient protective equipment necessary for the interventions which involved the transportation of patients suspect or confirmed with the new Coronavirus. The meeting ended with the issuance of the Decision No. 1 from 29 January 2020, issued by the Technical-Scientific Support Group on the management of highly contagious diseases in Romania. Between January 2020 and October 2020, 55 decisions and orders associated with the pandemic situation were issued. The first case of SARS-CoV 2 infection was reported in Romania on 26 February 2020.

Here are several decisions, orders, guidelines and recommendations issued between January 2020 and October 2020:

- Guideline of medical analyzes for COVID 19, Guide of OBBCSSR (Order of Biochemists, Biologists and Chemists in the Romanian Health System) from 30 April 2020.

- Order no. 555 of 03 April 2020 in which the COVID hospitals and the COVID Support hospitals are nominated (it subsequently underwent multiple modifications).

- Decision of the Constitutional Court of Romania no. 458 from 25 June 2020 with effect from 02 July 2020 prohibiting quarantine and isolation.

- 02 July 2020 - 21 July 2020 = LEGAL VACUUM.

- The law and the two orders that regulate the management of the COVID 19 Pandemic on the Romanian territory starting with 21 July 2020. 
- The law published in the Official Gazette no. 634, Part I, of 18 July 2020, entered into force on 21 July 2020.

- Order of the Romanian Ministry of Health no. 1039 of 21 July 2020.

- Order of the Romanian Ministry of Health no. 1321 of 22 July 2020.

- Protocol for the treatment of SARS$\mathrm{CoV}-2$ virus infection, issued by the Ministry of Health on 07 August 2020 and in force since 10 August 2020, published in the Official Gazette Part I, no. 719 from 10 August 2020.

- COVID 19 patient surveillance methodology, updated on 14 October 2020 - a document drafted by the National Center for Surveillance and Control of Communicable Diseases.

\section{Material and Methods}

Between 27 March - 31 August 2020145 patients were hospitalised in the general surgery and plastic surgery departments of the Colentina Clinical Hospital, a Covid-19 support hospital (2). The organisation of patients into categories can be seen in Table 1. Patients who underwent surgery due to the emergency of the surgical pathology can be found in Table 2 .

Eleven surgeries were performed in the general surgery departments Between 27
March - 31 August 2020, while in the same period of the previous year, we had approximatively 1200 surgeries (Table 3).

Out of the 14 patients who underwent surgery (of which 3 underwent plastic surgery), 1 patient was Covid negative (transferred to a non-Covid hospital), 1 patient required a reintervention, 4 patients died (cardio-respiratory complications with a heart attack), 3 patients were retransferred (2 patients after Covid negativity and 1 positive patient to another support hospital), 6 patients were discharged (5 Covid negative patients and 1 Covid positive patient).

The analysis of the 145 patients infected with SARS-CoV-2 and treated in the Colentina Surgery Clinic during MarchAugust 2020, included the following factors: the main diagnosis at hospitalisation, age, gender, comorbidities, surgery in another hospital before hospitalisation, intervention during the hospitalisation in the Colentina Surgery Clinic, COVID-19 infection confirmed before the hospitalisation in the Colentina Surgery Clinic, the period in which the patient was discharged according to the regulations in force at the time of discharge, the duration of the negative test for COVID-19, the duration of hospitalisation, laboratory tests at admission and during hospitalisation $(\mathrm{Hb}, \mathrm{WBC}, \mathrm{Neu}, \mathrm{Lym}$, Fibrinogen, PCR, procalcitonin, ferritin,

Table 1. Organization of patients by categories

\begin{tabular}{llc}
\hline 1 & Patients who underwent surgery due to the urgency of the surgical pathology & 14 \\
\hline 2 & Patients in whom elective interventions were performed & 1 \\
\hline 3 & $\begin{array}{l}\text { Patients operated in other surgical services and sent to the Colentina Surgery Clinic after COVID 19 } \\
\text { screening for surveillance to COVID 19 until RT-PCR COVID 19 test becomes negative }\end{array}$ & 38 \\
\hline 4 & $\begin{array}{l}\text { Patients with surgical pathology hospitalized in other services for elective operations, diagnosed with COVID 19 } \\
\text { and sent to the Colentina Surgery Clinic for COVID 19 treatment }\end{array}$ & 16 \\
\hline 5 & Patients admitted directly to the Intensive Care Unit on a surgical record, without having a surgical diagnosis & 16 \\
\hline 6 & Patients admitted to the surgical department without having a surgical diagnosis & 26 \\
\hline 7 & $\begin{array}{l}\text { Patients with surgical pathology, other than those with recent surgical interventions, who went to other surgical } \\
\text { services and were transferred to the Colentina Surgery Clinic, following the detection of COVID-19 infection }\end{array}$ & 26 \\
\hline 8 & Patients admitted to the Colentina Surgery Clinic, but with specialized treatment performed on other surgical departments & 1 \\
\hline 9 & $\begin{array}{l}\text { COVID 19 positive patients, hospitalized in other COVID-19 hospitals, who, during hospitalization in those hospitals } \\
\text { were diagnosed with surgical pathologies and were transferred to the Colentina Surgery Clinic for specialized treatment }\end{array}$ & 4 \\
\hline 10 & $\begin{array}{l}\text { Patients transferred to the Colentina Surgery Clinic from other departments of the Colentina Hospital, due to the appearance } \\
\text { of surgical pathologies }\end{array}$ & 3 \\
\hline
\end{tabular}


Table 2. Patients who underwent surgery due to the urgency of the surgical pathology

1 A 57-year-old patient: thigh amputation for wet lower left limb gangrene - death 4 days postoperatively;

2 A 36-year-old patient with peritonitis due to perforated bulbar ulcer - ulcer excision was performed with simple suture, lavage, drainage; the patient was suspected of having Covid. After 2 consecutive negative PCR tests, the patients was immediately transferred to a non-Covid surgery department;

3 A 48-year-old patient with intestinal occlusion due to pelvic tumor recurrence after sigmoid tumour operated on in November 2019 - ileostomy was performed; Covid-negative at the moment of discharge;

4 A 75-year-old patient with entero-mesenteric infarction - segmental enterectomy with end-to-end entero-entero-anastomosis was performed; Covid-positive at the moment of transfer to another support hospital;

5 A 71-year-old patient with appendicular breastplate - exploratory laparotomy, toilet, drainage - death 4 days postoperatively;

6 A 37-year-old patient with deep bilateral sacro-gluteal eschar - surgical debridement of devitalized tissues; Covid-negative at the moment of transfer.

7 A 38-year-old patient with open finger wound - surgical debridement, proximal flap take-off; Covid-positive at the moment of discharge on request;

8 A 70-year-old patient with gastric blunt ADK operated in another service - haemorrhage of pancreatic origin, choledocho-duodenal and jejunal-pancreatic fistula and evisceration - had hemostasis; Covid-negative at the moment of transfer to another non-Covid hospital surgery department;

9 A 71-year-old patient with metacarpal 2 comminutive fracture due to dog bite - soft and bone tissue debridement; Covid-negative at the moment of discharge;

10 A 63-year-old patient with acute gangrenous cholecystitis, gallbladder liver abscess - classic cholecystectomy, liver abscess drainage; Covid-negative at the moment of discharge;

11 A 60-year-old patient - generalized peritonitis by right colon perforation - right hemicolectomy with terminal ileostomy - death 4 days postoperatively;

12 A 67-year-old patient with gangrene toes 4 and 5 left foot - amputation; Covid-negative at the moment of discharge;

13 A 69-year-old patient with anterior abdominal wall hematoma, hemoperitoneum - hemostasis, toilet, drainage - reoperation at 24 hours hemoperitoneum (anticoagulated patient with Fragmin at Victor Babeș Hospital) - death 4 days after reintervention;

14 A 47-year-old patient with open wound on the right hand - surgery at Plastic Surgery - soft tissue surgical debridement, tenoraphy common extensor tendon and own finger V, suture of the remaining wounds; Covid-negative at the moment of discharge;

Table 3. Comparison between the number of surgeries performed in the Surgery Clinic of the Colentina Clinical Hospital during April-August 2020 and April-August 2019

\begin{tabular}{lcc}
\hline In the pandemic period & Discharges & Operations \\
27 March -31 August 2020 & 145 & 11 \\
\hline Before the pandemic period & Monthly discharges & Monthly operations \\
& 250 & 240 \\
\hline Total operations & 11 & April-August 2019 \\
& In the pandemic period April-August 2020 & 1.200 \\
\hline
\end{tabular}

D-dimers, INR, APT, PT), imaging suggestive for COVID-19 infection, drug treatment, side effects, ventilatory support, type of discharge (at home, transferred, deceased).
The hospitalisation period varied from one to 62 days (Fig. 1).

Of the total of 145 patients hospitalised and treated in the Surgery Clinic of the Colentina
Figure 1. The hospitalization period varied between one day and 62 days
70

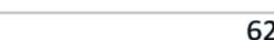

60

50

40

30

20

10

0

12234556789910111213141516171819202122232425262728293031

Days of hospitalization

Patients 
Figure 2. Number of operated vs. unoperated patients during hospitalization in the Colentina Surgery Clinic

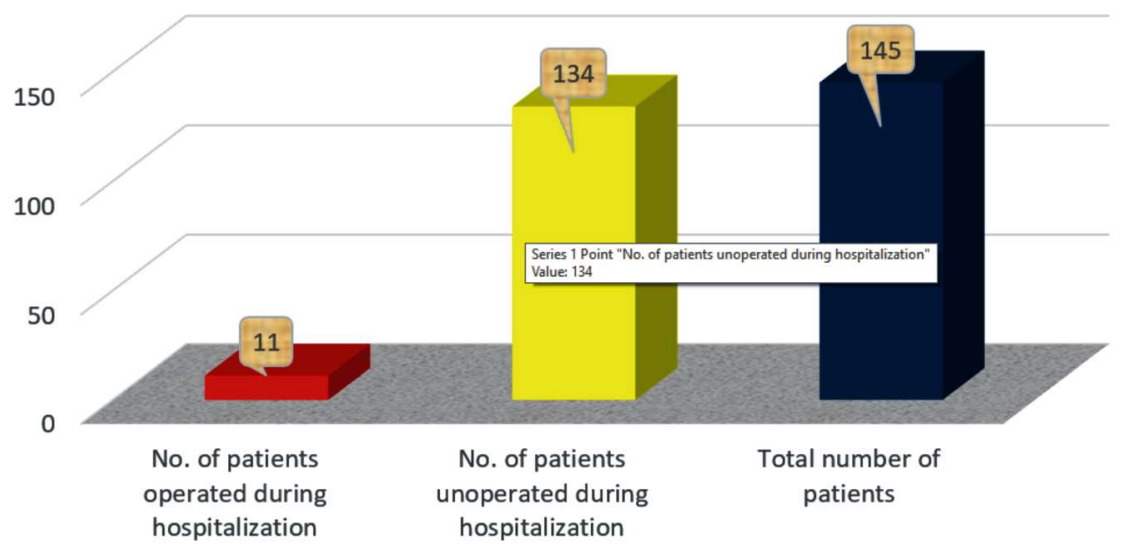

Clinical Hospital, only 11 patients underwent surgery during hospitalisation (Fig. 2); 89 patients were negative until discharge (Fig. 3).

Of the 145 patients, COVID-19 pneumonia was imaged (chest CT) in 21 patients, 79 patients having suggestive images $(\mathrm{Rx}$ and CT) for COVID-19 infection (Fig. $4 A, B$, Fig. 5 A, B, O).

Out of the total number of hospitalised patients 35 patients died, out of which 20 patients had surgical diagnoses, and 15 patients had medical diagnoses (Fig. 6 A,B, O). Three patients died from bleeding due to excess anticoagulant therapy (Heparin).

\section{Pathophysiology - SARS-CoV-2 Infection May Induce a Procoagulant Status}

There are more and more reports of COVID-19 positive cases with thrombotic events. A study (3) published in late April in the JACC (Journal of the American College of Cardiology) (4) draws attention to the predisposition of those infected with SARS-CoV-2 to both arterial and venous thrombosis caused by excessive inflammation and subsequent platelet activation, endothelial dysfunction and blood stasis. The therapeutic implications are to be considered by physicians, as most patients with severe diseases have an anticoagulant or antiplatelet agent in their treatment regimen. Among the haematological changes recorded so far, the most common were the following:

- thrombocytopenia has been considered a predictor of severe forms or death; some data revealed 5 times higher risk of death (5) for patients with low platelet counts;
Figure 3. Number of days until the RT - PCR COVID-19 test became negative (89 patients out of 145 did not become negative until the moment of discharge)

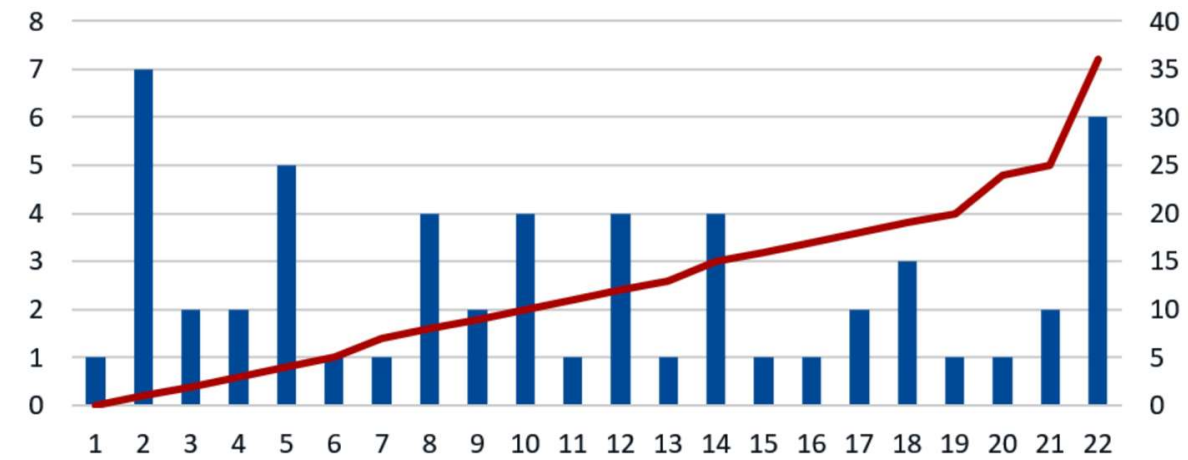

No. of patients $\longrightarrow$ No. of days until the RT-PCR COVID 19 test become negative 
Figure 4. CT images suggestive $\mathbf{A}$ for COVID-19 infection
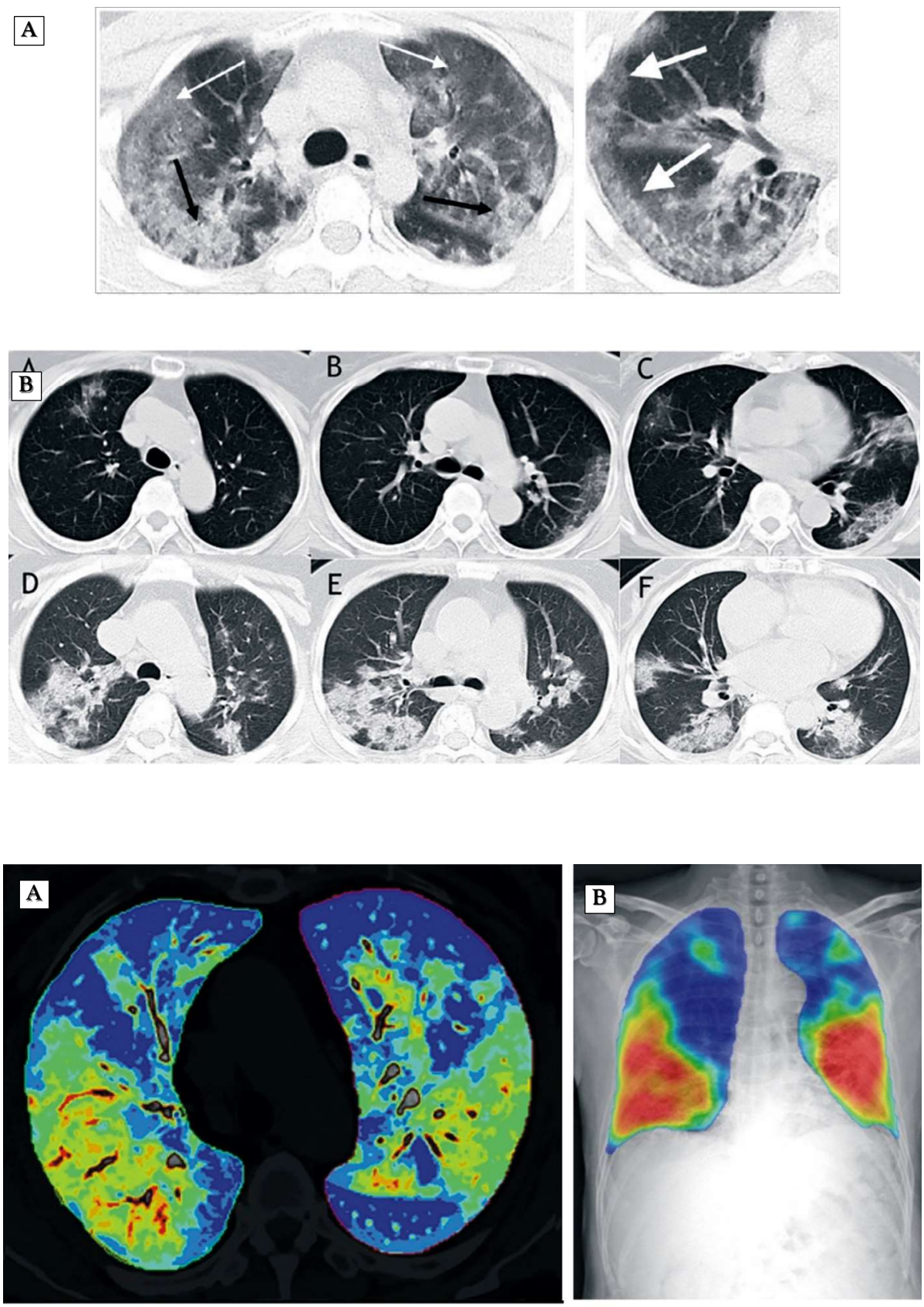

Figure 5. Pulmonary $X$-ray suggestive for COVID-19 infection

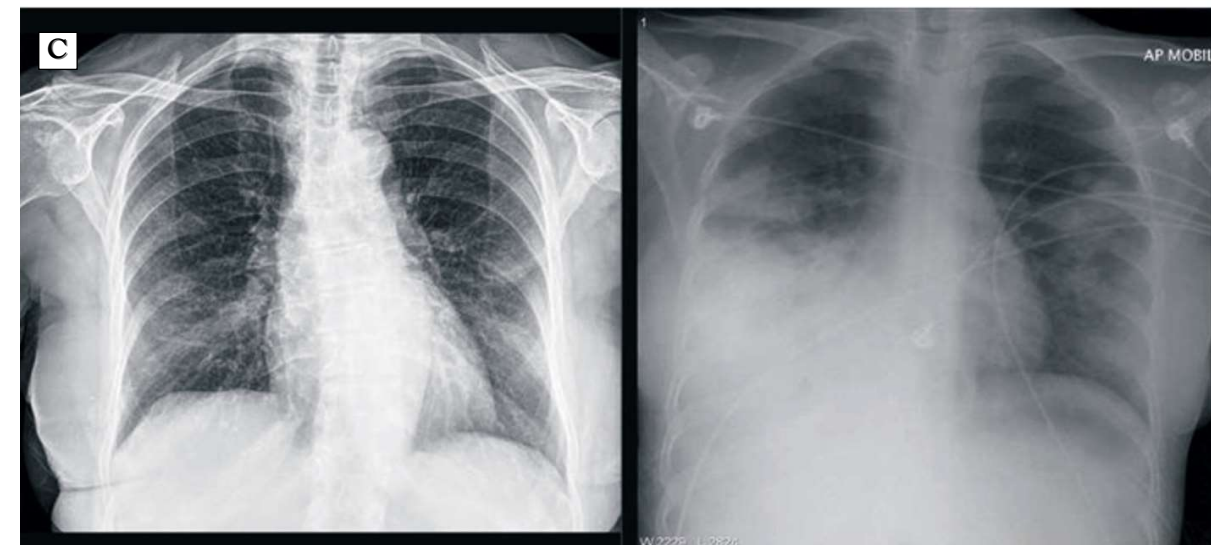


Figure 6A. Number of patients who died out of the total number of hospitalized patients

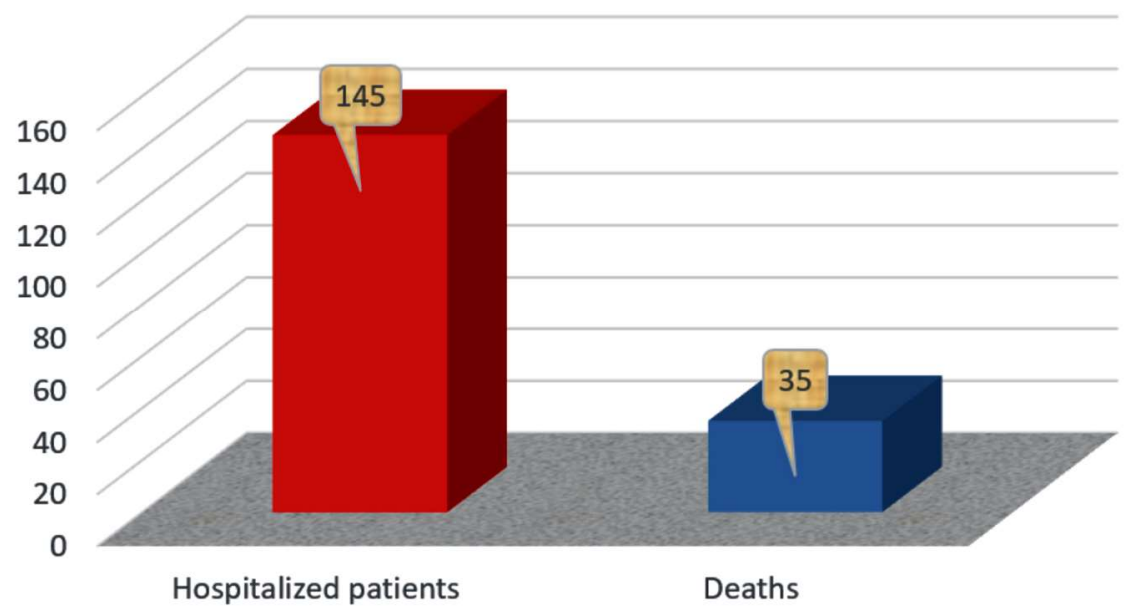

\begin{tabular}{ll}
\hline 1 & Other unspecified intestinal obstructions \\
\hline 2 & Other bowel obstructions \\
\hline 3 & Malignant stomach tumour without specification \\
\hline 4 & Malignant tumor, lesion exceeding the larynx \\
\hline 5 & Internal haemorrhoids with other complications \\
\hline 6 & Granuloma due to the presence of a foreign body of the skin \\
and subcutaneous cellular tissue
\end{tabular}

Figure 6. (B) 20 patients died with surgical diagnoses

- D-dimers and fibrin degradation products (PDF) above normal are associated with an increased risk of developing a severe form of infection (6), which requires mechanical ventilation or hospitalisation in intensive care;

- Coagulation times are frequently below normal in COVID-19 positive patients, leading to pro-coagulation status.
1 Bleeding by anticoagulant overdose

2 Unspecified myelodysplastic syndrome

3 Unspecified respiratory failure

4 Acute respiratory failure

5 Other forms of diabetes mellitus with peripheral angiopathy, gangrene

6 Influenza with pneumonia, identified influenza virus

7 Other specified types of sepsis

8 Atherosclerosis of the arteries of the extremities with pain at rest

9 Unspecified coronaviral infection

10 Acute respiratory failure

11 Paralytic ileus

12 Other interstitial lung diseases with fibrosis

13 Other viral pneumonias

14 COVID-19 with an identified virus

15 Other specified types of sepsis

Figure 6. (C) 15 deceased patients with medical diagnoses

The concentration of D-dimers in the blood is correlated with increased mortality in COVID-19 positive patients (7).

Regarding thrombotic prophylaxis for COVID-19 positive patients with multiple associated comorbidities, no conclusive data are yet available. These patients should be advised to avoid sedentariness (8) in quarantine, and pharmaceutical prophylaxis should be currently reserved for those at high risk of thrombosis. The latter category could include people with major disabilities, limited mobility, those with a history of deep vein 
Figure 7. Comorbidities presented by hospitalized 40 patients

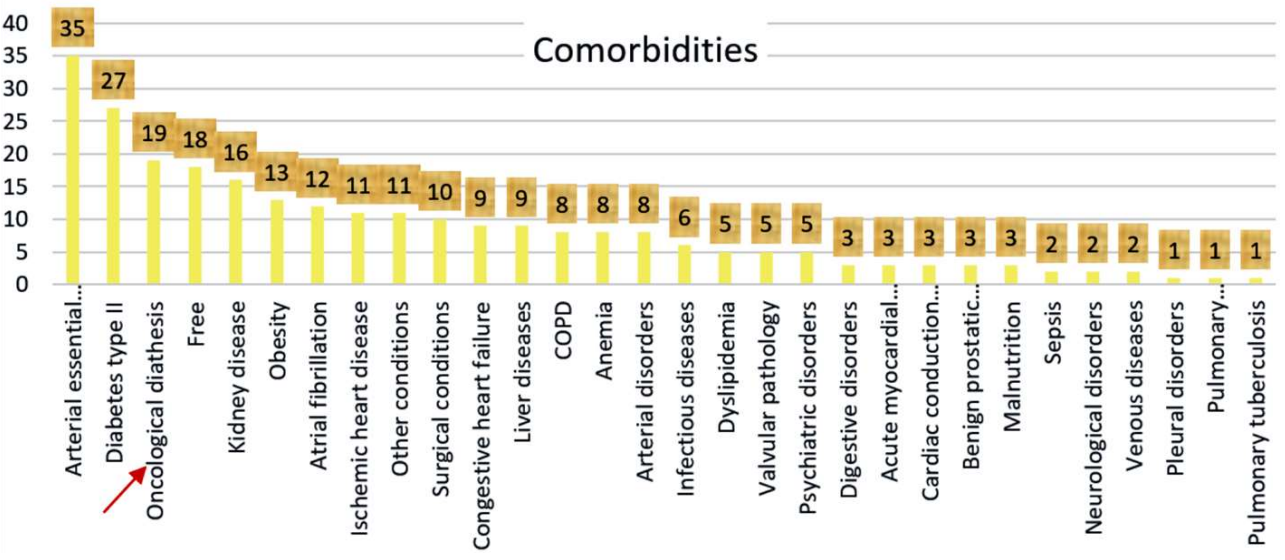

Figure 8. Specific medication used

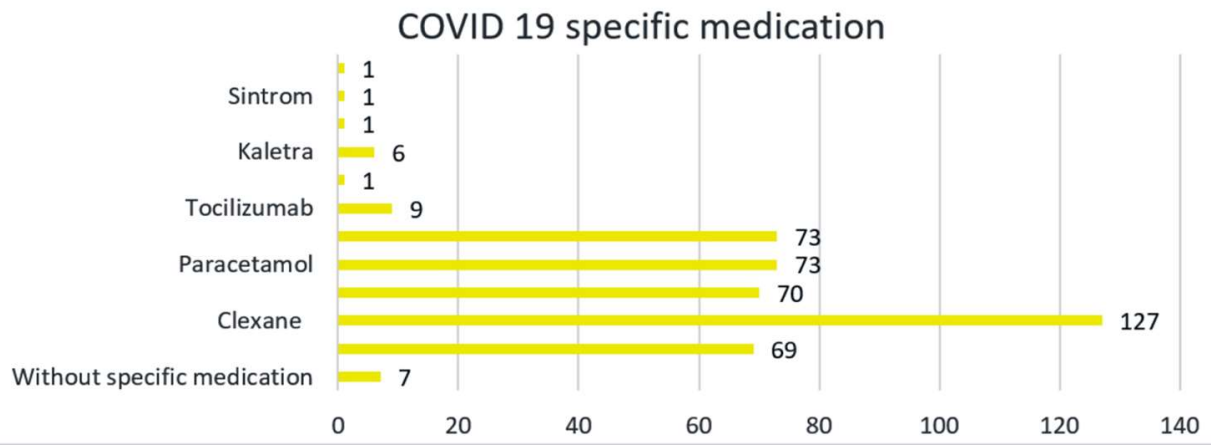

thrombosis or active neoplastic processes.

More than 15 clinical trials have been initiated to elucidate the relationship between pro-coagulant status and SARS-CoV-2 infection. The investigation of the interactions between anticoagulant (9) or antiplatelet agents and COVID-19 is necessary both for the appropriate treatment (10) of patients already on antithrombotic therapy and for the prevention (11) of thrombosis in those without associated comorbidities.

Hospitalised patients presented several types of comorbidities (Fig. $\lambda$ ).

The specific medication used was mainly Dexamethasone, Paracetamol, Azithromycin, Clexane and Plaquenil (Fig. 8); Plaquenil has recently been discontinued due to potentially fatal side effects (QT prolongation on ECG, risk of malignant arrhythmias). The main adverse effects of medical therapy were QT prolongation, nausea and vomiting, bleeding and rash (Fig. 9).

\section{Rehabilitation of Respiratory Function after COVID-19 Infection}

Although the medium- and long-term impact of COVID-19 infection on the respiratory system and other organs has not been yet determined in patients cured and discharged, according to experts, about a quarter of them remain with respiratory sequelae and a

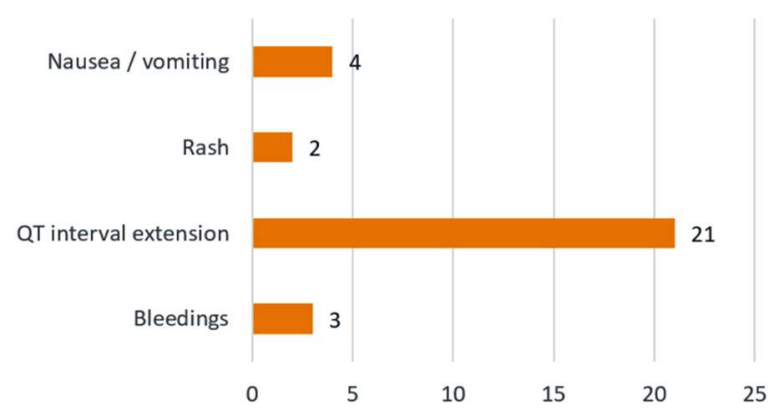

Figure 9. The main side effects of medical therapy 
reduced lung capacity by about $20-30 \%$. These patients present varied symptomatology: dyspnea, asthenia, fatigue, limitations of the capacity of effort, limitations of daily activities, all these affecting life quality (12).

Respiratory rehabilitation is an evidencebased therapeutic method developed by a multidisciplinary team that addresses patients with dyspnea (shortness of breath) and decreased tolerance to effort due to respiratory exertion deficiency. It helps, along with medications, to reduce the shortness of breath and increase exercise capacity. The program will include patients who have symptoms (dyspnea, fatigue, cough) and a reduction of tolerance to exercise and difficulties to perform daily activities due to respiratory disease. Respiratory rehabilitation consists of an adapted exercise program (individually or in groups) and an educational program (management of the condition and symptoms) (12). The rehabilitation team consists of a medical rehabilitation specialist, general assistant, kinesiotherapist, physiotherapist, psychologist.

\section{Discussions}

1. For 5 months (27 March 31 August 2020), when Colentina Clinical Hospital functioned as an exclusive Covid support hospital, 145 patients were hospitalized in the general surgery and plastic surgery service, of which only 14 patients underwent surgery. In the same period of the previous year, 1253 patients were hospitalized and 1207 operations were performed.

2. For the positive Covid patient, the main medical concern is to obtain the infectiouscontagious disease negativity the eventual surgical pathology benefiting from surgical intervention only in case of emergency.

3. In the case of oncological patients, it is recommended to perform the surgery after obtaining infectious-contagious disease negativity, and the oncological treatment is interrupted during the Covid-positive period (to avoid more immunological disturbance).

4. Death occurred in 35 cases. Of the 14 patients operated during hospitalisation in Colentina Clinical Hospitall, four of them died (all the 14 cases were surgical emergencies in Covid patients).

5. The leading cause of death: respiratory decompensation, disturbance of fluidcoagulation balance, multiple organ damage (Covid myocarditis, Covid nephropathy, Covid hepatopathy, etc).

6. Although Romania does not have a leading place in the total number of diseases, there are high mortality values for the Covid-19 patients; this situation can be explained by a combination of delayed diagnosis of Covid and pre-existing poor health in these patients.

7. The primary paraclinical investigations related to the evolution of Covid-19 were:

- D-dimers, ferritin, IL6, CRP, fibrinogen;

- pulmonary imaging: thoracic CT (gold standard), thoracic X-ray.

8. The main substances used in the treatment of the disease were:

- Clexane;

- Dexamethasone;

- Azithromycin;

- Plaquenil (hydroxychloroquine);

- Kaletra (Lopinavir + Ritonavir);

- Tocilizumab (IL6 inhibitor);

- Remdesivir (nucleotide analogue);

- Plasma rich in antibodies from cured Covid 19 patients (unclear results).

9. The legal regulations have varied a lot since the emergence of the first Covid-19 case in Romania (26 February 2020), but four main periods can be distinguished:

- 27 March - 14 May 2020 (state of emergency, compulsory hospitalisation of all Covid patients even asymptomatic and discharge only after 2 negative PCRCovid tests),

- 15 May - 02 July 2020 (alert status, the continuation of previous measures),

- 03 July - 20 July 2020 (LEGAL VACUUM following the Constitutional Court of Romania decision which eliminated the compulsory hospitalisation of Covid patients),

- 21 July - 31 August 2020 (hospitalisation 
only of symptomatic patients, the possibility of discharge after 14 days even in positive PCR-Covid test conditions).

10. In 89 cases, RT-PCR-Covid negativity occurred after more than 36 days following the admission.

11. The duration of hospitalisation in the Colentina Surgery Clinic varied between one day (8 patients) and 62 days (2 patients).

12. The quality of immunity developed in cured Covid 19 patients is uncertain, hence the discussion on the therapeutic quality of plasma, as well as protection against further illness and the effective vaccine to protect against contracting the disease.

13. The main activity of surgeons in Colentina Clinical Hospital has become mainly the medical care of patients operated in other surgical services or monitoring the evolution of patients with chronic surgical pathologies until obtaining a negative Covid test to allow their transfer to other surgical departments where they could undergo surgery.

14. The practical didactic activity (students, residents, research, etc.) was abruptly stopped. The theoretical component continued online.

15. The complex cases began to exceed the competence of physicians, and another problem emerged. Malpractice insurances didn't cover the treatment of an infectious pathology by surgeons. The presence of an infectious disease consultation in the observation sheet of these patients was mandatory!

16. RT-PCR-SARS-CoV-2 is still the only test considered for screening and diagnosis, although it has been found to have a margin of error of $20-30 \%$.

17. Rehabilitation of severe cases of Covid-19 requires a process of lung rehabilitation after healing; the medium-long term analysis will show the complexity of the changes induced in the human body by the disease (pulmonary, neurological sequelae etc).

\section{Conclusions}

1. Colentina Surgery Clinic was the first medical facility in Romania to perform surgical activities exclusively on Covid patients. Thus, it was the only institution in Romania to have this kind of experience. Following the decision of 16 March 2020, Colentina Clinical Hospital was designated the only Covid Support Hospital in Bucharest. This decision was initially based on the proximity to the National Institute of Infectious Diseases "Prof. Dr. Matei Bals", a criterion that soon became utterly irrelevant.

2. Shortly after understanding how the entire Covid situation is functioning, it became apparent that the primary medical effort was in the pulmonology and intensive care unit departments; the surgical activity dedicated to Covid patients is performed at values of approximate $1 \%$ compared to the period before the pandemic began.

3. The Romanian health system will have to adapt to the new situation, in which the Covid-19 disease is just one of the other human pathologies. Soon, all hospital units will have to organize their own Covid sectors in which they can ensure the adequate treatment of these patients, without cancelling the possibility for other patients to benefit from the medical services of the medical teams. In this way, the possibility of positive discrimination will be avoided for all the socio-human categories involved: patients, doctors, university staff, etc.

4. Covid-19 is a contagious disease with a primary pulmonary expression that benefits in severe cases of pneumology treatment $+/$ - intensive care unit treatment, the other medical-surgical specialities having a tangential and transient connection.

5. Covid-19 is a public health problem that will continue to test the health systems of the world's states for at least the next 1-2 years. 


\section{Author's Contributions} All authors contributed equally to the
manuscript.

\section{Conflict of Interest}

The authors declare no conflicts of interests.

\section{Ethics Approval}

For performing this study ethical approval was obtained.

\section{References}

1. https://umfcd.ro/ce-stim-despre-sars-cov-2-si-covid19/. Material written by Cosmina Stoican, Razvan Papacocea under the guidance of Prof. Dr. Simona Ruta.

2. Internal Data - Colentina Clinical Hospital, Bucuresti, Romania.

3. Bikdeli B, Madhavan MV, Jimenez D, Chuich T, Dreyfus I, Driggin E, et al. COVID-19 and Thrombotic or Thromboembolic Disease: Implications for Prevention, Antithrombotic Therapy, and FollowUp: JACC State-of-the-Art Review. J Am Coll Cardiol. 2020; 75(23):2950-2973. Epub 2020 Apr 17.
4. Journals of the American College of Cardiology; link: https://www.jacc.org/.

5. Thrombocytopenia is associated with severe coronavirus disease 2019 (COVID-19) infections: A meta-analysis; Giuseppe Lippia, Mario Plebanib, Brandon Michael Henry; link:https://www. sciencedirect.com/science/article/abs/pii/S0009898120301248

6. Prominent changes in blood coagulation of patients with SARSCoV-2 infection; Huan Han, Lan Yang, Rui Liu, Fang Liu, Kai-Lang Wu, Jie Li, Xing-Hui Liu, Cheng-Liang Zhu; link:https://pubmed. ncbi.nlm.nih.gov/32172226/.

7. Clinical course and risk factors for mortality of adult inpatients with COVID-19 in Wuhan, China: a retrospective cohort study; link: https://www.thelancet.com/journals/lancet/article/PIIS01406736(20)30566-3/fulltext.

8. Regular endurance exercise may reduce the risk of severe COVID19 lung complications. The impact of physical activity on the risk of respiratory infections - Amelia Voinea; link: https://raportuldegarda.ro/articol/impact-pandemie-covid19-sedentarism-scaderenivel-activitate-fizica-risc-infectii-respiratorii-anduranta-antioxidanti-ards/.

9. A Randomized Trial of Anticoagulation Strategies in COVID-19; link: https://clinicaltrials.gov/ct2/show/NCT04359277?term=Anticoagul ants\&cond $=$ COVID\&draw $=3$

10. Preventing COVID-19 Complications With Low- and High-dose Anticoagulation (COVID-HEP); link: https://clinicaltrials.gov/ct2/ show/NCT04345848?term=Anticoagulants\& cond=COVID\&draw $=2$

11. Protective Effect of Aspirin on COVID-19 Patients (PEAC); link: https://clinicaltrials.gov/ct2/show/NCT04365309?term=Anticoagul ants\&cond=COVID\&draw $=2$

12. http://www.inrmfb.ro/wp-content/uploads/2020/04/ GP_ post COVID19.pdf. 